\title{
Preparation and Characterization of some Transition Metal Complexes with Two Mixed Ligands Macrocyclic and Ligands $\mathbf{P P h}_{3}$
}

\author{
Falah M. Fakhree* \\ Department of Nursing/Bardarash Technical Institute/ Duhok Polytechnic University \\ Saad Kh. Dawood \\ Department of Chemistry/ College of Science/ University of Mosul \\ *E-mail: falah.fakhri@dpu.edu.krd
}

(Received $10 / 10 / 2018$; Accepted $30 / 7$ /2019)

\begin{abstract}
A new ligand $\left(3,4,6,14,15,17,23,24\right.$-octaazatricyclo $\left[17.3 .1 .1^{8}, 12\right]$ tetracosa-1(23),8(24),9,11, 19, 21- hexaene - 2,5,7,13,16,18 - hexaone), (CHT) was been prepared from the reaction of pyridine-2,6-dicarboxylic acid with semicarbazide using microwave irradiation in solid state. The ligand is reacted with some transition metal(II) ions to form complexes of the type $[\mathrm{Co}(\mathrm{CHT})] \mathrm{Cl}_{2}, \quad[\mathrm{Fe}(\mathrm{CHT}) \mathrm{Cl}] \mathrm{Cl}$ and $\left[\mathrm{M}\left(\mathrm{CHT} \mathrm{Cl}_{2}\right]\right.$ where $(\mathrm{M}=\mathrm{Mn}(\mathrm{II}), \mathrm{Ni}(\mathrm{II}), \mathrm{Cu}(\mathrm{II})$ and $\mathrm{Zn}(\mathrm{II}))$. Complexes of the type $\left[\mathrm{Ni}(\mathrm{CHT})\left(\mathrm{PPh}_{3}\right)\right] \mathrm{Cl}_{2}$ and $\left[\mathrm{M}(\mathrm{CHT})\left(\mathrm{PPh}_{3}\right) \mathrm{Cl}\right] \mathrm{Cl}$ where $(\mathrm{M}=\mathrm{Mn}(\mathrm{II}), \mathrm{Fe}(\mathrm{II})$, $\mathrm{Co}(\mathrm{II}), \mathrm{Cu}(\mathrm{II})$ and $\mathrm{Zn}(\mathrm{II})$ ), were prepared by the reaction of the above complexes with triphenylphosphine $\left(\mathrm{PPh}_{3}\right)$ in a 1:1 molar ratio. All the complexes were characterized by $(\mathrm{C}, \mathrm{H}, \mathrm{N})$ analysis, metal content analysis, molar conductance, magnetic moment measurements, electronic and IR spectroscopy, as well as the ligand was characterized by ${ }^{1} \mathrm{H},{ }^{13} \mathrm{C}-\mathrm{NMR}$. The electronic spectra and magnetic measurements indicate that the complexes have octahedral environment around the metal ions, except cobalt complex have square planer geometry.
\end{abstract}

Keywords: Macrocyclic Ligand, Microwave Irradiation.

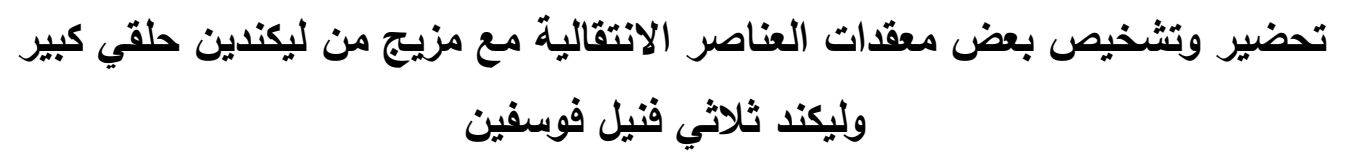

الملخص

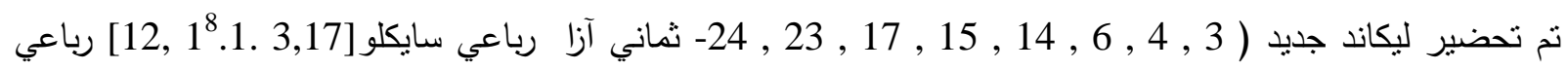

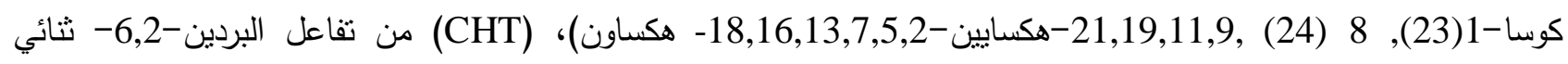

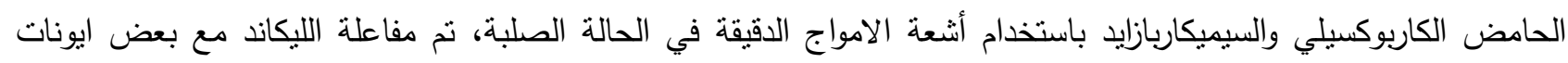
العناصر الأنتقالية لتكوين معقدات من النـوع

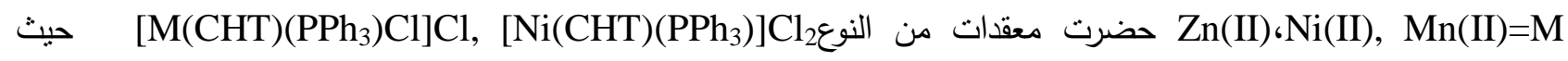

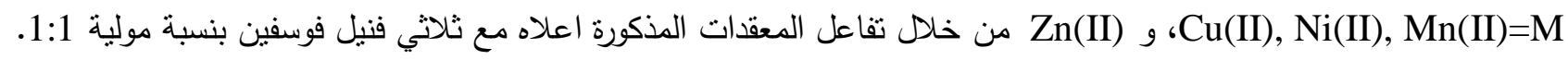
شخصت جميع المعقدات بواسطة التحليل الدقيق للعناصر(C,H,N) وتقدير المحتوى الفلزي وقياسات التوصيلية الكهربائية المولارية و العزوم المغناطيسية والاطياف الأكترونية وطيف الأثتعة تحت الحمراء، بالإضافة إلى ذلك فقد نم تشخص الليكاند

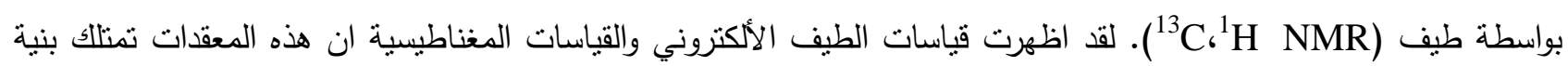
ثمانية السطوح حول الايون الفلزي. باستثناء معقد الكوبلت (II) الذي يمنلك بنية المربع المستوي. الكلمات الدالة: ليكاند حلقي كبير ، أثعة الأمواج الدقبقة.

\section{INTRODUCTION}


Macrocyclic compounds received much attention by many author's Robson macrocyclic (Lever, 1970; Dawood et al., 2013; Xiaoqi et al., 2018; Al-Daher et al., 2018). Owing to their metal coordinating properties, metal ions are able in several favorable cases, to organize reacting molecular fragments according to specific geometry and drive the reaction toward the formation of cyclic compound. Transition metal macrocyclic compound have an active part of metalloenzymes as bionomic model compounds due to their resemblance with natural proteins like hemerythrin and enzymes (Zhang et al., 2012).

Poly aza macrocyclic compounds modified with tetraamide and hexaamide function a cyclic tetra peptide moieties in capsulate bind metal ions without deprotonation process of the amide group and are capable to stabilize even the low oxidation states of the metal ions (Kantekin et al., 2010). On other hand not only the above macro molecules ligands form complexes with transition metals but also they were mixed with the phosphine. Macrocyclic phosphine hold promise as incredibly stable ligands for applications requiring robust complexes such as radio active transition metal complexes for use as radiopharmaceuticals. Because of this possibility, these ligand and their complexes have been synthetic targets since soon after the macrocyclic effect was discovered (Rajesh et al., 2012).

Microwave techniques for preparation of organic substances have received a great deal of attention due to their various advantages such as selectivity, rapid and direct controllable internal reactions. This technique has been used to prepare an eighteen member ring ligand and it's reaction with transition metal ion's to form a new complexes of different geometries

(Lever et al., 1970).

In view of these interesting results and as continuation of our studies on transition metal complexes with macrocyclic ligand (Dawood, 2010; Dawood et al., 2011; Dawood et al ., 2012), we have prepared new types of complexes containing different donor atoms using microwave technique.

\section{Materials and Methods}

\section{EXPERIMENTAL}

All chemicals used as supplied from BDH and Fluka companies. IR spectra were recorded on a Fourier-Transform (FT.IR) Spectrophotometer Tensor 27 Co. Brucker in the range (400 - 4000 $\mathrm{cm}^{-1}$ ) using $\mathrm{KBr}$ discs. The $\mathrm{CHN}$ analysis carried out by (Euro Vactor Model E A 3000) in ALAlbeit University -Jordan. element analysis of the ligand and its complexes (PYE UNICAM SP9Atomic Absorption Spectrophotometer) at the Department of Biology, Mosul University. Conductivity measurements were carried out on $10^{-3} \mathrm{M}$ solution of the complexes in DMSO using (Conductivity Meter Model PCM3-JENWAY), electronic spectra were recorded on (Shimadzu-UVVisible recording, UV-1650PC-spectrophotometer), using $10^{-3} \mathrm{M}$ of the complexes in DMSO. The magnetic susceptibility were measured at $25{ }^{\circ} \mathrm{C}$ by Farady's method using Bruker BM6 instrument. ${ }^{1} \mathrm{H}-\mathrm{NMR}$ and ${ }^{13} \mathrm{C}-\mathrm{NMR}$ were carried out by(BRUKER $300 \mathrm{MHz}$ (Switzerland )) and shimadzu QP $5050 \mathrm{~A}(\mathrm{JAPAN})$ at Al-Albeit University - Jordan. The ligands prepared in solid state using microwave oven type morph Richards EM 820 CPT. Melting points of all compounds were measured using electro thermal 9300 engineering apparatus and were uncorrected.

\section{Preparation of the Ligand (CHT):}

The ligand (CHT), (Scheme 1), Fig. (1), has been synthesized according to the following equation in below and procedure (Neerja et al., 2010). A solid pyridine-2,6-dicarboxylic acid $(3.34 \mathrm{~g}, 0.002 \mathrm{~mol})$ was mixed with solid $(0.15 \mathrm{~g}, 0.002 \mathrm{~mol})$ semicarbazide and $(0.005 \mathrm{~g}$, $0.0001 \mathrm{~mol})$ of cerium ammonium nitrate $(\mathrm{CAN})$ as a catalyst. The solid mixture was irradiated using a microwave $800 \mathrm{~W}$ for 10 minutes. The mixture cooled at room temperature, then ethyl acetate $(20 \mathrm{ml})$ was added and the mixture stirred for about $1 \mathrm{hr}$ to dissolve the CAN which 
separated from the mixture by filtration, the gray precipitate was washed with n- hexane, ethanol and dried under vacuum for several hours. The physical properties are listed in (Table 1).

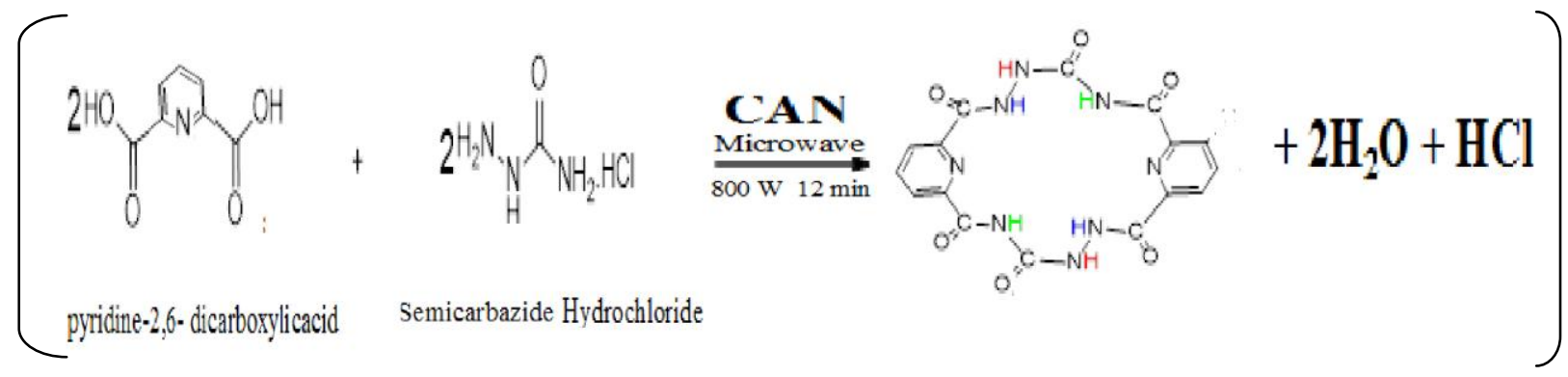

Scheme-1- Preparation of the Ligand (CHT)

\section{Preparation of $[\mathrm{Co}(\mathrm{CHT})] \mathrm{Cl}_{2},[\mathrm{Fe}(\mathrm{CHT}) \mathrm{Cl}] \mathrm{Cl}$ and $\left[\mathrm{M}(\mathrm{CHT}) \mathrm{Cl}_{2}\right]$ (where $\mathrm{M}=\mathrm{Mn}(\mathrm{II}), \mathrm{Ni}(\mathrm{II}), \mathrm{Cu}(\mathrm{II})$ and $\mathrm{Zn}(\mathrm{II}))$ :}

The solution of the ligand (CHT) $(0.42 \mathrm{~g}, 0.001 \mathrm{~mole})$ in $(10 \mathrm{ml}) \mathrm{DMF}$ and ethanol solution of $(0.001$ mole $)$ of metal chloride $\left[\mathrm{MnCl}_{2} .4 \mathrm{H}_{2} \mathrm{O}(0.198 \mathrm{~g})\right.$; $\left[\mathrm{FeCl}_{2} \cdot 4 \mathrm{H}_{2} \mathrm{O}(0.198 \mathrm{~g})\right.$; $\left[\mathrm{CoCl}_{2} \cdot 6 \mathrm{H}_{2} \mathrm{O}\right.$ $(0.238 \mathrm{~g}) ;\left[\mathrm{NiCl}_{2} \cdot 6 \mathrm{H}_{2} \mathrm{O}(0.234 \mathrm{~g}) ;\left[\mathrm{CuCl}_{2} \cdot 2 \mathrm{H}_{2} \mathrm{O}(0.170 \mathrm{~g}) ;\left[\mathrm{ZnCl}_{2}(0.132 \mathrm{~g})\right]\right.\right.$ were mixed together with stirring. The mixture was refluxed for $2 \mathrm{hr}$. After cooling the precipitate was filtered off washed with cold ethanol then dried under vacuum.

\section{Preparation of mixed ligand complexes $\left[\mathrm{Ni}(\mathrm{CHT})\left(\mathrm{PPh}_{3}\right)\right] \mathrm{Cl}_{2}$ and $\left[\mathrm{M}(\mathrm{CHT})\left(\mathrm{PPh}_{3}\right) \mathrm{Cl}\right] \mathrm{Cl}$ (where $\mathrm{M}=\mathrm{Mn}(\mathrm{II}), \mathrm{Fe}(\mathrm{II}), \mathrm{Co}(\mathrm{II}), \mathrm{Cu}(\mathrm{II})$ and $\mathrm{Zn}(\mathrm{II})$ )}

The metal complexes [Fe(CHT)Cl]Cl $(0.54 \mathrm{~g}, .0001 \mathrm{~mol})$ was dissolved in $(10 \mathrm{ml}) \mathrm{DMF}$ and added to a solution of triphenylphosphine $(0.26 \mathrm{gm}, 0.001 \mathrm{~mol})$ in $(10 \mathrm{ml})$ ethanol , the mixture was refluxed for $1 \mathrm{~h}$. The precipitate that formed was filtered off, washed with diethylether and dried under vacuum. Same procedure was carried out to prepare the other complexes of $(\mathrm{Co}(\mathrm{II})$, $\mathrm{Ni}(\mathrm{II}), \mathrm{Cu}(\mathrm{II}), \mathrm{Zn}(\mathrm{II})$ ).

\section{RESULTS AND DISCUSSION}

Microwave irradiation of a mixture of the semicarbazid, dicarboxylic acid and CAN catalyst afforded the ligand (CHT) in 90\% Yield, which is stable in air, non-hydroscopic at room temperature. C.H.N analyses, melting point, and other physical properties for the ligand are listed in (Table 1). The complexes and the mixed ligand complexes are stable, non-hydroscopic and have high melting points, the physical properties are listed in (Table 1).

The ligand (CHT) characterized by ${ }^{1} \mathrm{H}$ NMR (Table 2) Fig. (2) and the chemical shift's data are listed in. Table (2) the band at $\delta(8.6 \mathrm{ppm})$ attributed to $6 \mathrm{H}(\mathrm{H}-$ py ring) assisted by the integration. The band at $\delta(8.6 \mathrm{ppm})$ and $\delta(7.2 \mathrm{ppm})$ attributed to $4 \mathrm{H}$ for the $\mathrm{NH}-\mathrm{NH}-\mathrm{CO}-$ pyr group ,and $\delta(11.2 \mathrm{ppm})$ attributed to $2 \mathrm{H}$ for the $(\mathrm{N}-\mathrm{H})$ group (Sternhell et al., 1969).

Table (3), Fig. (3) contains ${ }^{13} \mathrm{C}-\mathrm{NMR}$ chemical shift's $(160 \mathrm{ppm})$ for $(\mathrm{N}-\mathrm{CO}-\mathrm{N}),(165 \mathrm{ppm})$ for (-CO-py) and (140 ppm) for (C-py meta), (148.9 ppm) for (C-py ortho), (128 ppm) for (C-pyr Para), the atom carbon of solvent (DMSO) to show at(40 ppm) in (Table 3), and Fig. (3) assist the structure of the ligand (Levy et al 1972).

The conductivity measurements indicted that the complexes $(1,4,5,6)$ are nonelectrolytes , while the complexes $(2,7,8,9,11,12)$ and $(3,10)$ are electrolytes as $(1: 1)$ and (1:2) respectively (Table 1).

The IR spectrum data of (CHT). Table (4) exhibited absorption frequencies assignable to $v(\mathrm{~N}-\mathrm{H})$ stretching as a strong band at $\left(3250 \mathrm{~cm}^{-1}\right), \delta\left((\mathrm{N}-\mathrm{H})\right.$ appears at $\left(1306 \mathrm{~cm}^{-1}\right), \mathrm{v}(\mathrm{N}-\mathrm{N})$ stretching vibration appears at $\left(1001 \mathrm{~cm}^{-1}\right)$, and the frequency assignable to $v(\mathrm{C}=\mathrm{O})$ band at $\left(1708 \mathrm{~cm}^{-1}\right)$ as medium intensity (Nakamoto, 1997). The IR spectrum characteristic to $v(\mathrm{~N}-\mathrm{N})$, $v(\mathrm{CO}-\mathrm{NH}-\mathrm{CO})$ and $\mathrm{v}(\mathrm{C}=\mathrm{O})$ stretching frequencies confirm the condensation reaction between 
the carboxylic acid and semicarbazide, to form a 20 membered hexa amide macrocycle CHT, as shown in Fig. (1). On complication, the stretching frequencies of $v(\mathrm{~N}-\mathrm{H}), \delta(\mathrm{CO}-\mathrm{NH}-\mathrm{CO})$ and $v(\mathrm{~N}-\mathrm{N})$ shifted to lower frequency, which may indicate the coordination of two $(\mathrm{NH})$ from the semicarbazide group Fig. (1), other support of this coordination comes from the appearance of new bands attributed to $v(\mathrm{M}-\mathrm{N})$ stretching at $\left(434-492 \mathrm{~cm}^{-1}\right)$. However, the position of $v(\mathrm{C}=\mathrm{O})$ stretching vibration has not been shifted frequencies in all complexes (Sulekh, 2005 ; Zafar, 2004). New bands in the spectrum of the complexes appeared between $(434-501) \mathrm{cm}^{-1}$ vibration of $\mathrm{v}(\mathrm{M}-\mathrm{N})$ group in all complexes may prove the coordination nitrogen atoms with metal ions.

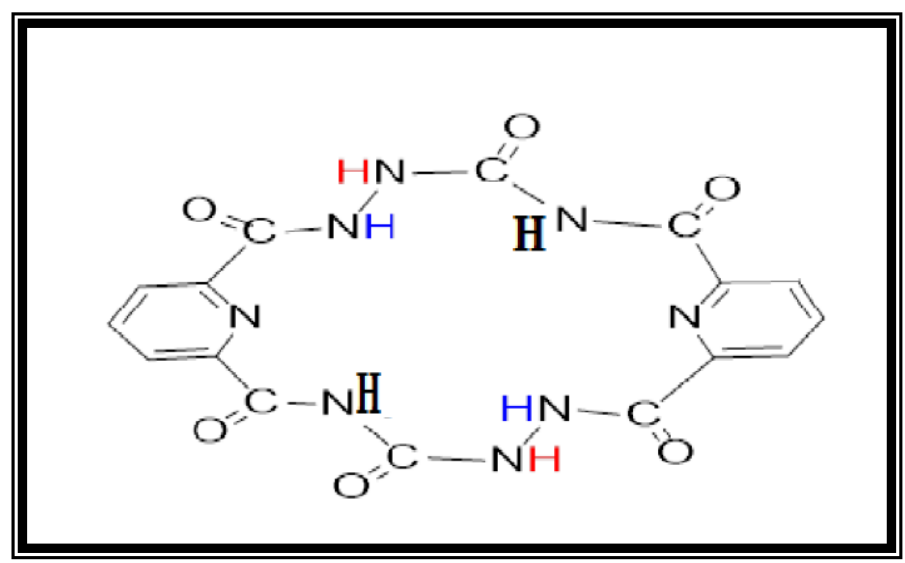

Fig. 1 : Structure of the ligand CHT

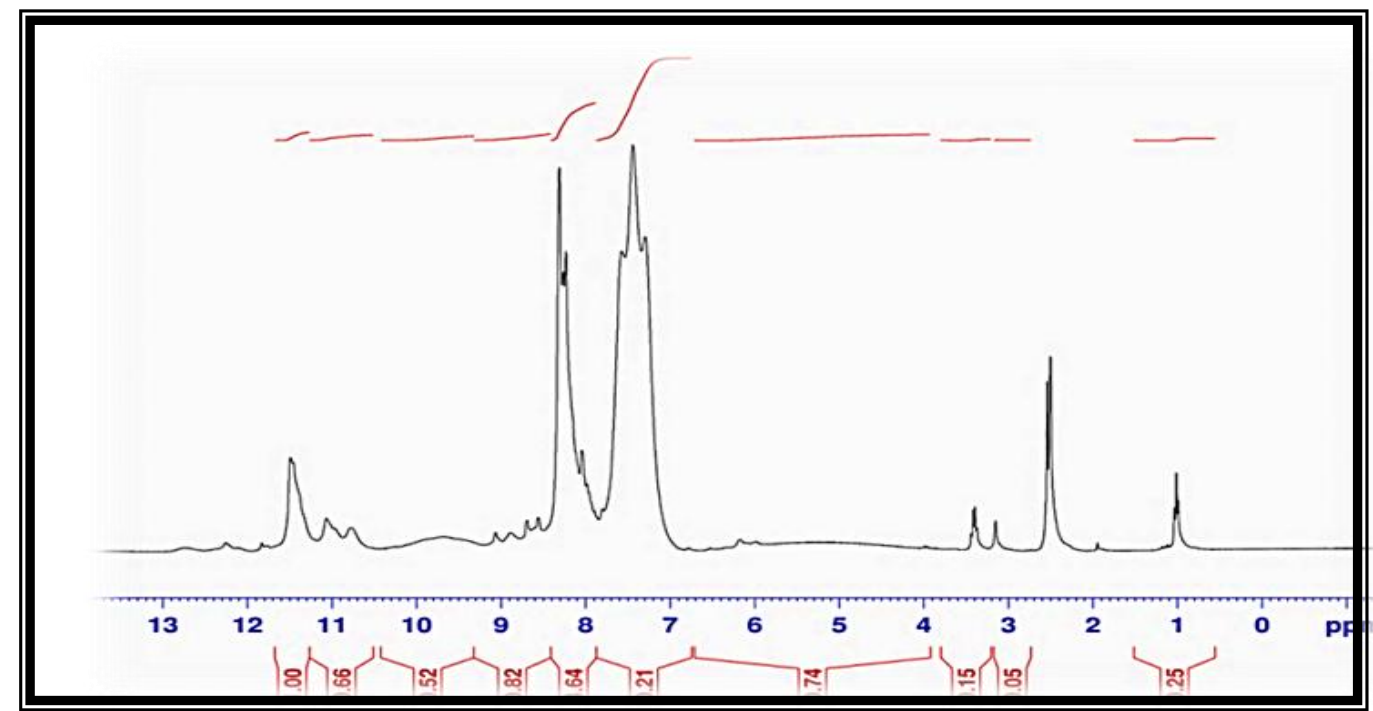

Fig. $2:{ }^{1} \mathrm{H}-\mathrm{NMR}$ for CHT ligand 


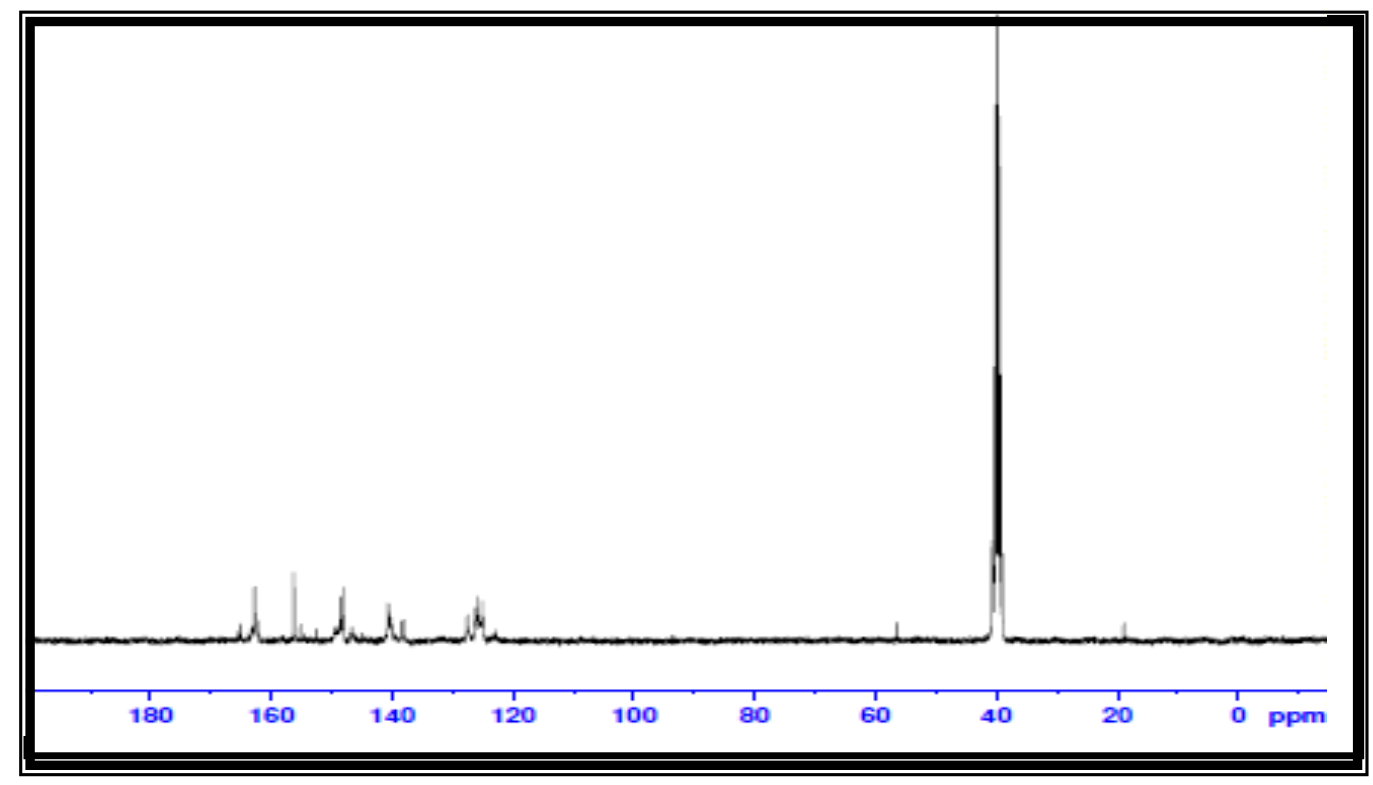

\section{Electronic Spectra and Magnetic Measurements}

Fig . $3:{ }^{13} \mathrm{C}$ - NMR for CHT ligand

The magnetic moments and electronic spectra data for all the complexes are given in (Table 5). The spectrum of the CHT ligand has bands in the U.V spectra at $\left(45871\right.$ and $\left.36760 \mathrm{~cm}^{-1}\right)$, assigned to $\pi \longrightarrow \pi^{*}$ and $\mathrm{n} \longrightarrow \pi^{*}$ transition, respectively. These values are shifted to lower frequencies ( $328-1229 ; 264-4080) \mathrm{cm}^{-1}$ respectively in the spectrum of the complexes.

The two manganese complexes number $(1,7)$ have a magnetic moment ( $5.99,5.88$ B.M) corresponding to five unpaired electrons, while the U.V - visible spectrum show bands at $\left(34482-48543 \mathrm{~cm}^{-}\right),\left(30121,37962 \mathrm{~cm}^{-1}\right)$ which may be due to charge transfer, indicating octahedral structure (Lever, 1970).

The magnetic moment values for the Fe(II) complexes number $(2,8)$ have a magnetic moment values $(4.87,5.12$ B.M $)$ as well as the electronic band at $\left(10526-10224 \mathrm{~cm}^{-1}\right)$ one attributed to the ${ }^{5} \mathrm{~T}_{2} \mathrm{~g} \longrightarrow{ }^{5} \mathrm{Eg}$ transition, show bands at $\left(32679,34482 \mathrm{~cm}^{-1}\right),\left(929230,36764 \mathrm{~cm}^{-}{ }^{1}\right)$ which may be due to charge transfer, indicating octahedral structure (shakir et al., 1995).

The cobalt complexes number $(3,9)$ have a magnetic moment values $(2.61,4.80$ B.M). Complex (9) is corresponding to three unpaired electrons (Table 5).The U.V- visible spectra show three bands at $\left(10245 \mathrm{~cm}^{-1}\right),\left(15625 \mathrm{~cm}^{-1}\right),\left(16889 \mathrm{~cm}^{-1}\right)$ due to the transition ${ }^{4} \mathrm{~T}_{1} \mathrm{~g}(\mathrm{~F}) \longrightarrow \mathrm{T}_{2} \mathrm{~g}(\mathrm{~F})$ $\mathrm{v}_{1},{ }^{4} \mathrm{~T}_{1} \mathrm{~g}(\mathrm{~F}) \longrightarrow{ }^{4} \mathrm{~A}_{2} \mathrm{~g}(\mathrm{~F}) \mathrm{v}_{2}$ and ${ }^{4} \mathrm{~T}_{1} \mathrm{~g}(\mathrm{~F}) \longrightarrow{ }^{4} \mathrm{~T}_{1} \mathrm{~g}(\mathrm{P}) \mathrm{v}_{3}$, respectively, and $\left(32051 \mathrm{~cm}^{-1}\right)$ which may be due to charge transfer. These data may of complex number 9 attribute to octahedral structure but complex (3) the U.V- visible spectra show bands at $\left(18181 \mathrm{~cm}^{-1}\right)$ due to the transitions ${ }^{2} \mathrm{~A}_{1} \mathrm{~g} \longrightarrow{ }^{2} \mathrm{Eg},\left(32679 \mathrm{~cm}^{-1}\right)$ which may be due to charge transfer, indicating square planer and similar results were found else where (Sulekh et al., 2004).

The UV - visible spectra of the Ni (II) complexes number $(4,10)$ shows three bands at $\left(10181,10111 \mathrm{~cm}^{-1}\right),\left(14679,15337 \mathrm{~cm}^{-1}\right)$ and $\left(23412,22676 \mathrm{~cm}^{-1}\right)$ corresponding to three spin allowed transition ${ }^{3} \mathrm{~A}_{2} \mathrm{~g}(\mathrm{~F}) \longrightarrow{ }^{3} \mathrm{~T}_{2} \mathrm{~g}(\mathrm{~F})\left(\mathrm{v}_{1}\right),{ }^{3} \mathrm{~A}_{2} \mathrm{~g}(\mathrm{~F}) \longrightarrow{ }^{3} \mathrm{~T}_{1} \mathrm{~g}(\mathrm{~F})\left(\mathrm{v}_{2}\right)$, and ${ }^{2} \mathrm{~A}_{2} \mathrm{~g}(\mathrm{~F}) \longrightarrow{ }^{3} \mathrm{~T}_{1} \mathrm{~g}(\mathrm{P})\left(\mathrm{v}_{3}\right)$, respectively, $\left(35211,36761 \mathrm{~cm}^{-1}\right)$ which may be due to charge transfer. The magnetic moment values $(3.04,2.99$ B.M) agree with high spin configuration indicating an octahedral environment around the Ni(II)ions (San et al., 2007).

The magnetic moment of the $\mathrm{Cu}$ (II) complexes number $(5,11)$ lie in the range $(2.16,1.94$ B.M), corresponding to one unpaired electron and electronic spectra have a band in the range $\left(16667,17391 \mathrm{~cm}^{-1}\right)$ assigned to the ${ }^{2} \mathrm{E}_{2} \mathrm{~g}(\mathrm{~F}) \longrightarrow{ }^{2} \mathrm{~T}_{2} \mathrm{~g},\left(32051,32679 \mathrm{~cm}^{-1}\right)$ which may be due to charge transfer, indicating distorted octahedral environment (Lever et al., 1970). 
The $\mu_{\text {eff }}$ values of the two $\mathrm{Zn}$ (II) complexes number $(6,12)$ were diamagnetic as expected, while the U.V - visible spectrum show bands at $\left(30121,37962 \mathrm{~cm}^{-}\right),\left(33121,41025 \mathrm{~cm}^{-1}\right)$ which may be due to charge transfer, indicating an octahedral environment around the $\mathrm{Zn}$ (II)ions

Table 1: Some physical properties including molar conductance and elemental analysis data of the all complexes

\begin{tabular}{|c|c|c|c|c|c|c|c|c|}
\hline \multirow[t]{2}{*}{ No } & \multirow[t]{2}{*}{ Compound } & \multirow[t]{2}{*}{ Color } & \multirow[t]{2}{*}{$\stackrel{\text { M.P, }}{{ }^{\circ} \mathbf{C}}$} & \multicolumn{4}{|c|}{$\begin{array}{c}\text { CHN } \\
\begin{array}{c}\text { Elemental analysis data found } \\
(\text { Calculated \%) }\end{array}\end{array}$} & \multirow[t]{2}{*}{$\begin{array}{c}\text { Molar } \\
\text { conductan } \\
\text { ce } \\
\Omega-1 \\
\text { cm2.mol }\end{array}$} \\
\hline & & & & $\% \mathrm{C}$ & $\% \mathrm{H}$ & $\% \mathrm{~N}$ & $\begin{array}{c}\text { Metal } \\
\%\end{array}$ & \\
\hline CHT & $\mathrm{C}_{16} \mathrm{H}_{12} \mathrm{~N}_{8} \mathrm{O}_{6}$ & Gray & 158 & $\begin{array}{c}51.18 \\
(51.58)\end{array}$ & $\begin{array}{c}6.16 \\
(6.47)\end{array}$ & $\begin{array}{c}19.90 \\
(20.34)\end{array}$ & - & - \\
\hline 1 & {$\left[\mathrm{Mn}(\mathrm{CHT}) \mathrm{Cl}_{2}\right]$} & Pale yellow & 63 & - & - & - & $\begin{array}{c}10.21 \\
(10.01) \\
\end{array}$ & 21 \\
\hline 2 & {$[\mathrm{Fe}(\mathrm{CHT}) \mathrm{Cl}] \mathrm{Cl}$} & Deep brown & 80 & $\begin{array}{c}35.65 \\
(34.93)\end{array}$ & $\begin{array}{c}2.24 \\
(2.04)\end{array}$ & $\begin{array}{c}20.79 \\
(19.61)\end{array}$ & $\begin{array}{c}10.36 \\
(10.28)\end{array}$ & 48 \\
\hline 3 & {$[\mathrm{Co}(\mathrm{CHT})] \mathrm{Cl}_{2}$} & Deep green & 105 & - & - & - & $\begin{array}{c}10.87 \\
(10.77)\end{array}$ & 86 \\
\hline 4 & {$\left[\mathrm{Ni}(\mathrm{CHT}) \mathrm{Cl}_{2}\right]$} & Pale brown & 70 & - & - & - & $\begin{array}{c}10.83 \\
(10.80)\end{array}$ & 16.5 \\
\hline 5 & {$\left[\mathrm{Cu}(\mathrm{CHT}) \mathrm{Cl}_{2}\right]$} & Deep brown & 60 & - & - & - & $\begin{array}{c}11.62 \\
(11.51)\end{array}$ & 19 \\
\hline 6 & {$\left[\mathrm{Zn}(\mathrm{CHT})(\mathrm{CHT}) \mathrm{Cl}_{2}\right]$} & Light Gray & 175 & $\begin{array}{c}35.03 \\
(34.21) \\
\end{array}$ & $\begin{array}{c}2.20 \\
(2.10)\end{array}$ & $\begin{array}{c}20.43 \\
(19.85)\end{array}$ & $\begin{array}{c}11.92 \\
(11.80)\end{array}$ & 5.6 \\
\hline 7 & $\left.\left[\mathrm{Mn}(\mathrm{CHT}) \mathrm{PPh}_{3}\right) \mathrm{Cl}\right] \mathrm{Cl}$ & Pale brown & 75 & - & - & - & $\begin{array}{c}6.68 \\
(6.56)\end{array}$ & 42 \\
\hline 8 & $[\mathrm{Fe}(\mathrm{CHT}) \mathrm{PPh} 3) \mathrm{Cl}] \mathrm{Cl}$ & Green Cloud & 110 & $\begin{array}{c}50.74 \\
(50.94)\end{array}$ & $\begin{array}{c}13.37 \\
(13.16)\end{array}$ & $\begin{array}{c}13.37 \\
(13.15)\end{array}$ & $\begin{array}{c}6.97 \\
(6.77)\end{array}$ & 34 \\
\hline 9 & {$\left[\mathrm{Co}(\mathrm{CHT})\left(\mathrm{PPh}_{3}\right) \mathrm{Cl}\right] \mathrm{Cl}$} & Blue & 60 & $\begin{array}{c}50.76 \\
(51.21)\end{array}$ & $\begin{array}{c}13.33 \\
(13.22)\end{array}$ & $\begin{array}{c}3.36 \\
(3.26)\end{array}$ & $\begin{array}{c}7.33 \\
(7.11)\end{array}$ & 35.5 \\
\hline 10 & {$\left[\mathrm{Ni}((\mathrm{CHT}))\left(\mathrm{PPh}_{3}\right)\right] \mathrm{Cl}_{2}$} & Light Green & 80 & $\begin{array}{c}50.78 \\
(51.51)\end{array}$ & $\begin{array}{c}13.33 \\
(12.85)\end{array}$ & $\begin{array}{c}3.36 \\
(3.19)\end{array}$ & $\begin{array}{c}7.30 \\
(7.25)\end{array}$ & 70.5 \\
\hline 11 & $\left.\left[\mathrm{Cu}(\mathrm{CHT}) \mathrm{PPh}_{3}\right) \mathrm{Cl}\right] \mathrm{Cl}$ & Dark Green & 70 & - & - & - & $\begin{array}{c}7.85 \\
(7.58)\end{array}$ & 44.5 \\
\hline 12 & {$\left[\mathrm{Zn}(\mathrm{CHT})\left(\mathrm{PPh}_{3}\right) \mathrm{Cl}\right] \mathrm{Cl}$} & Pale yellow & 65 & - & - & - & $\begin{array}{c}8.06 \\
(7.95)\end{array}$ & 35 \\
\hline
\end{tabular}

Table 2: Chemical shift for ${ }^{1}$ H-NMR

\begin{tabular}{|c|c|c|c|c|}
\hline compound & NH-NH-CO-pyr & NH-NH-CO-pyr & N-H & H- pyr \\
\hline CHT & 7.2 & 8.1 & 11.2 & 8.6 \\
\hline
\end{tabular}

Table 3: Chemical shift for ${ }^{13} \mathrm{C}-\mathrm{NMR}$

\begin{tabular}{|c|c|c|c|c|c|}
\hline compound & N-CO-N & -CO-pyr & C-pyr meta & $\begin{array}{r}\text { C-pyr } \\
\text { ortho }\end{array}$ & C-pyr Para \\
\hline CHT & 160 & 165 & 140 & 148.9 & 128 \\
\hline
\end{tabular}


Table 4 : Selected I.R bands and their assignment in $\mathrm{cm}^{-1}$

\begin{tabular}{|c|c|c|c|c|c|c|}
\hline No & \multicolumn{7}{|c|}{ I.R spectra } \\
\hline & $\mathbf{v}(\mathbf{N}-\mathbf{H})$ & $\boldsymbol{\delta}(\mathbf{N}-\mathbf{H})$ & $\mathbf{v}(\mathbf{N}-\mathbf{N})$ & $\mathbf{v}(\mathbf{C}=\mathbf{O})$ & $\mathbf{v}(\mathbf{N}-\mathbf{P y r})$ & $\mathbf{v}(\mathbf{M}-\mathbf{N})$ \\
\hline CHT & 3250 & 1306 & 1001 & 1708 & 1520 & - \\
\hline 1 & $3168(\mathrm{w})$ & $1295(\mathrm{~s})$ & $943(\mathrm{~s})$ & $1709(\mathrm{~m})$ & 1520 & $434(\mathrm{~m})$ \\
\hline 2 & $3124(\mathrm{w})$ & $1267(\mathrm{~m})$ & $999(\mathrm{~m})$ & $1705(\mathrm{~m})$ & 1481 & $453(\mathrm{~m})$ \\
\hline 3 & $3167(\mathrm{w})$ & $1286(\mathrm{w})$ & $951(\mathrm{~m})$ & $1708(\mathrm{~m})$ & 1516 & $476(\mathrm{w})$ \\
\hline 4 & $3172(\mathrm{w})$ & $1298(\mathrm{~s})$ & $999(\mathrm{~s})$ & $1705(\mathrm{~m})$ & 1518 & $465(\mathrm{~m})$ \\
\hline 5 & $3197(\mathrm{w})$ & $1275(\mathrm{w})$ & $951(\mathrm{~m})$ & $1707(\mathrm{~m})$ & 1518 & $484(\mathrm{~m})$ \\
\hline 6 & $3211(\mathrm{~m})$ & $1277(\mathrm{~m})$ & $951(\mathrm{~s})$ & $1705(\mathrm{~s})$ & 1522 & $430(\mathrm{~m})$ \\
\hline 7 & $3192(\mathrm{w})$ & $1281(\mathrm{~m})$ & $999(\mathrm{~s})$ & $1707(\mathrm{~m})$ & 1518 & $542(\mathrm{~s})$ \\
\hline 8 & $3170(\mathrm{~m})$ & $1290(\mathrm{~m})$ & $941(\mathrm{~s})$ & $1706(\mathrm{~s})$ & 1522 & $453(\mathrm{~m})$ \\
\hline 9 & $3190(\mathrm{w})$ & $1279(\mathrm{~s})$ & $997(\mathrm{~s})$ & $1704(\mathrm{~m})$ & 1523 & $457(\mathrm{~m})$ \\
\hline 10 & $3201(\mathrm{w})$ & $1280(\mathrm{~s})$ & $951(\mathrm{~s})$ & $1705(\mathrm{~m})$ & 1482 & $465(\mathrm{~s})$ \\
\hline 11 & $3145(\mathrm{~m})$ & $1271(\mathrm{~m})$ & $951(\mathrm{~s})$ & $1707(\mathrm{~m})$ & 1518 & $501(\mathrm{~m})$ \\
\hline 12 & $3180(\mathrm{w})$ & $1281(\mathrm{~m})$ & $999(\mathrm{~m})$ & $1709(\mathrm{~m})$ & 1520 & $492(\mathrm{~m})$ \\
\hline
\end{tabular}

Table 5 : Magnetic moment and electronic spectral data of the complexes

\begin{tabular}{|c|c|c|c|}
\hline No & Compound & $\boldsymbol{\mu}_{\text {eff }}, \mathbf{B . M}\left(\mathbf{2 5}^{\mathbf{}} \mathbf{C}\right)$ & $\boldsymbol{\lambda}_{\mathbf{m a x}}\left(\mathbf{c m}^{\mathbf{- 1}}\right)$ \\
\hline 1 & {$\left[\mathrm{Mn}(\mathrm{CHT}) \mathrm{Cl}_{2}\right]$} & 5.99 & 34482,45543 \\
\hline 2 & {$[\mathrm{Fe}(\mathrm{CHT}) \mathrm{Cl}] \mathrm{Cl}$} & 4.87 & $10526,32679,34482$ \\
\hline 3 & {$[\mathrm{Co}(\mathrm{CHT})] \mathrm{Cl}_{2}$} & 2.61 & 18181,32679 \\
\hline 4 & {$\left[\mathrm{Ni}(\mathrm{CHT}) \mathrm{Cl}_{2}\right]$} & 3.04 & $10181,14679,23412,35211$ \\
\hline 5 & {$\left[\mathrm{Cu}(\mathrm{CHT}) \mathrm{Cl}_{2}\right]$} & 2.16 & 16667,32051 \\
\hline 6 & {$\left[\mathrm{Zn}(\mathrm{CHT})\left(\mathrm{CHT}_{2}\right) \mathrm{Cl}_{2}\right]$} & diamagnetic & 30121,37962 \\
\hline 7 & $\left.\left[\mathrm{Mn}(\mathrm{CHT}) \mathrm{PPh}_{3}\right) \mathrm{Cl}\right] \mathrm{Cl}$ & 5.88 & 33112,44642 \\
\hline 8 & $\left.\left[\mathrm{Fe}(\mathrm{CHT}) \mathrm{PPh}_{3}\right) \mathrm{Cl}\right] \mathrm{Cl}$ & 5.12 & $10224,29230,36760$ \\
\hline 9 & {$\left[\mathrm{Co}(\mathrm{CHT})\left(\mathrm{PPh}_{3}\right) \mathrm{Cl}\right] \mathrm{Cl}$} & 4.80 & $10245,15625, \quad 16889,32051$ \\
\hline 10 & {$\left[\mathrm{Ni}((\mathrm{CHT}))\left(\mathrm{PPh}_{3}\right)\right] \mathrm{Cl} l_{2}$} & 2.99 & $10111,15337,22676,36496$ \\
\hline 11 & $\left.\left[\mathrm{Cu}(\mathrm{CHT}) \mathrm{PPh}_{3}\right) \mathrm{Cl}\right] \mathrm{Cl}$ & 1.94 & 17391,32679 \\
\hline 12 & {$\left[\mathrm{Zn}(\mathrm{CHT})\left(\mathrm{PPh}_{3}\right) \mathrm{Cl}\right] \mathrm{Cl}$} & diamagnetic & 33121,44525 \\
\hline
\end{tabular}

\section{COUNCLUSION}

On the basis of the above results, we proposed the following structures [for all the complexes]. 

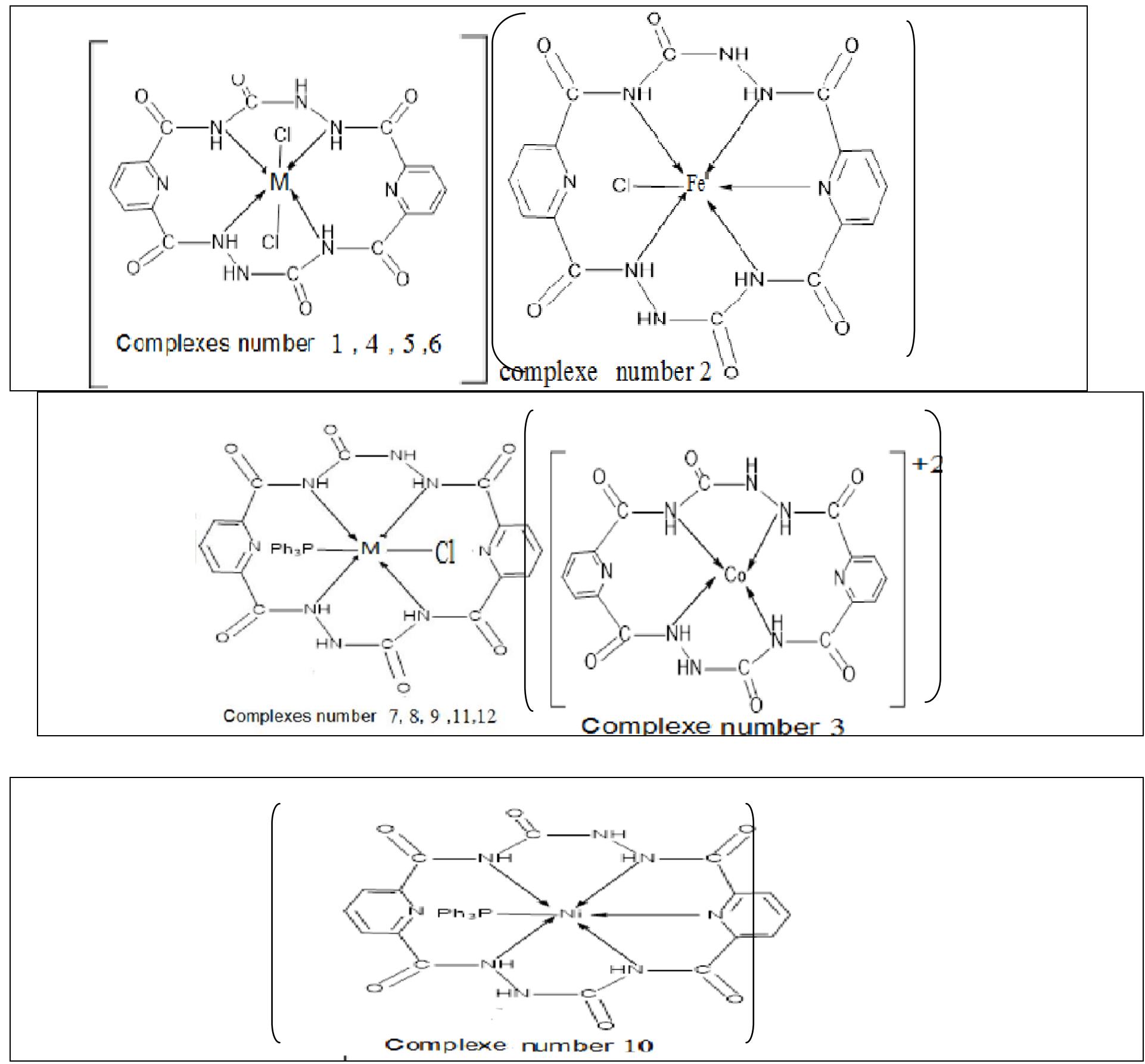

\section{REFERENCES}

Al-Daher, A.G.M.; Al-Qassar, I.A. (2018). Synthesis and Structural Studies of Co(II),Ni(II), $\mathrm{Cu}(\mathrm{II}) \mathrm{Zn}(\mathrm{II}), \mathrm{Th}(\mathrm{IV})$ and UO2(II) Complexes with 2- Acetylpyridine-4'-methylbenzoyl hydrazone. Raf. J. Sci., 27(1), 52-64.

Dawood, S.K.; Fakhree, M.F. (2013). New Complexes of ( 3, 4, 6, 13, 14, 16- hexaazatricyclo $[16,2,2,28,11]$ tetracosane-2,5,7,12,15,17-hexaone) with $\mathrm{Mn}(\mathrm{II}), \quad \mathrm{Fe}(\mathrm{II}), \quad \mathrm{Co}(\mathrm{II})$, $\mathrm{Ni}(\mathrm{II}), \mathrm{Cu}(\mathrm{II})$ and $\mathrm{Zn}(\mathrm{II})$. Raf. J. Sci., 24(3), 76-85

Dawood, S.K.; Thana, Y.Y. (2012). Characterization studies of Mn(II), Fe(II), Co(II), Ni(II), $\mathrm{Cu}$ (II) and $\mathrm{Zn}$ (II) complexes with new ligands derived from thiourea. J. Edu. and Sci ., 24(1), 22-28. 
Dawood, S.K. (2011). Synthesis and characterization of $\mathrm{Mn}(\mathrm{II}), \mathrm{Fe}(\mathrm{II}), \mathrm{Co}(\mathrm{II}), \mathrm{Ni}(\mathrm{II}), \mathrm{Cu}(\mathrm{II})$ and $\mathrm{Zn}(\mathrm{II})$ complexes with hexaazamacrocyclic ligands derived from thiosemicarbazide. J. Edu. and Sci ., 24(4), 60 -67.

Dawood, S.K.; Thana, Y.Y.; Israa, A.H. (2010). Transitions metal complexes of tetra dentat macrocyclic ligand 1,3,10,12-tetra aza - 4,9,13,18,tetraoxo-2,11- dithiacyclooctadecane and bipyridin. Tikrit J. Pure Sci., 15(3), 194-197.

Kantekin, H.G.; Dilber, A.N. (2010). Microwave-assisted synthesis and characterization of a new soluble metal-free and metallophthalocyanines peripherally fused to four 18 -membered tetrathiadiaza macrocycles. J. Org. Chem., 695(8),1210 - 1214.

Lever, A.B.P. (1970). "Crstar Field Spectra and Electronic Spectroscopy". Wiley Inter Science, New York, 110 p.

Lever, A.B.P. (1968). "Inorganic Electronic Spectroscopy". Elsevier., Amsterdam, 168 p.

Levy, G.C.; Nelson, C.L. (1972). "Carbon-13 Nuclear Magnetic Resonance for Organic Chemists" . New York ; Wiley. Inter Science. 39 p.

Nacamoto, K. (1997). "Infrared and Raman Spectra of Inorganic and Coordination Compounds". $5^{\text {th }}$ ed., John wily and Sons, Inc., New York, pp.87-89.

Neerja, G.; Ruby, N. (2010). CAN promoted synthesis of amid derivatives green technology for pharmaceuticals . International J. Pharma and Bio. Sci., 1,1-7.

Rajesh, J.A.; Gubendran, G.; Rajagopal; Atappan, P. (2012). Synthesis, spectra and DNA interactions of certain mononuclear transition metal(II) complexes of macrocyclic tetraaza diacetyl curcumin ligand. J. Mol. Structure., 169-1010.

Robson, R.; Pilkington, N.C. (1970). Complexes of binucleating ligands. III. Novel complexes of a macrocyclic binucleating ligand. Aust . J. Chem., 23, 2225 - 2236.

San, K.S.; Paulsamy, S.; Hari, N. (2007). Microwave assisted Synthesis of 72-membered chiral hexanuclear [6+6]macrocyclic Shiff base. J. Incl phenommacrocycle Chem., 959, 383-388.

Shakir, M.; Mohamed, A.K.; Varkey, S.P.; Nasman, M.; Siddiqi, Z.A. (1995). Transition metal complexes of 20-22-membered octaazamacrocycles. Synthesis and Characterization ., 14(10),1277.

Sulekh, C.; Lokesh, K. (2005). Electronic, EPR, magnetic and spectral studies and homobinuclear $\mathrm{Co}(\mathrm{II})$ and $\mathrm{Cu}(\mathrm{II})$ complexes with a novelmacrocyclic ligand. Spectrochemica Acta., Part A. (62), 1102-1106.

Sulekh, C.; Lokesh, K. (2004). Spectroscopic characterization of tetradentate macrocyclic ligamd and its transition metal complexes. Spectrochemica Acta., Part A. (60), 2767-2774 .

Sternhell, S.; Jackman (1969). "Application of Nuclear Magnetic Resonance in Organic Chemistry". Pergamon. $161 \mathrm{p}$.

Xiaoqi, Yu.; Zhang, Ji. (2018). "Macrocycli Polyamine Synthesis and Appliction". $1^{\text {th }}$ ed. Wiley-VCH, New Yourk, 232 p.

Zafar, A.S.; Shah, M.S. (2004). Novel 16-membered [N6] macrocylic bearin hexaamid function and their metal - ncapsulated compounds., Indian J. Chem., 43(A), 2274-2280

Zhang, Z.; Gao, W.-Y.; Wojtas, L.; Ma, S.; Eddaoudi, M.; Zaworotko (2012). Post-Synthetic modification of porphyrin-encapsulating metal-organic materials by cooperative addition of inorganic salts to enhance $\mathrm{CO} 2 / \mathrm{CH} 4$ selectivity. M. J. Angew Chem. Int. Ed., 51, 9330-9334. 